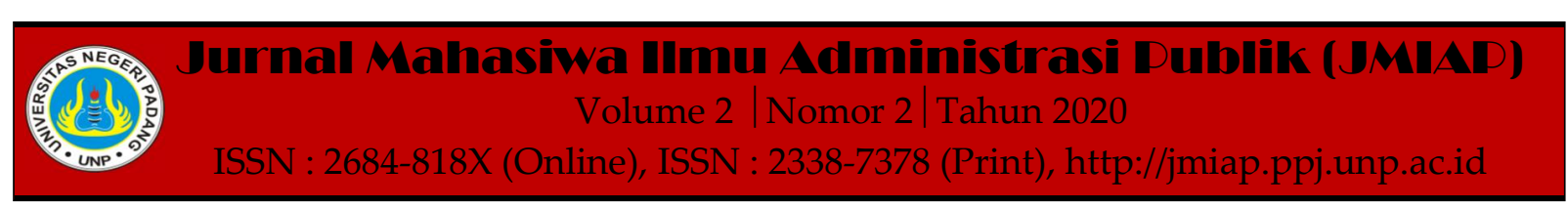

\title{
IMPLEMENTASI PERAN PEMERINTAHAN DAERAH DALAM PELESTARIAN POPULASI IKAN BILIH DI DANAU SINGKARAK BERDASARKAN PERATURAN GUBERNUR NOMOR 81 TAHUN 2017
}

\author{
Intan EImayu Putri ${ }^{1(a)}$, Syamsir ${ }^{2(b)}$ \\ ${ }^{1}$ Jurusan Ilmu Administrasi Negara, Universitas Negeri Padang \\ ${ }^{2}$ Jurusan Ilmu Administrasi Negara, Universitas Negeri Padang \\ a)intanelmayu08@gmail.com, ${ }^{b)}$ syamsirsaili@yahoo.com
}

\begin{abstract}
This research explains the role of regional governance in the preservation of the Bilih fish population in Lake Singkarak based on Gubenur regulation No 81 year 2017. Research aims to describe the role of local governance, constraints and efforts of local governance. Methods used are qualitative methods. Data is derived from documentation studies, interviews, and observations. Things that are considered in collecting data in the selection of informant among them to the community, community leaders, head of the field of capture and head of PRL and PSDKP and Walinagari. Based on the results of the research conducted in the service can be concluded: first, the role of the Marine Service and fisheries of West Sumatra province in the preservation of Bilih fish populations in the use of Centrum, Putas/poison, the vacuum and mesh that the net eyes are too tightly in Lake Singkarak. Second, the Marine Service and fisheries of West Sumatra province which is seen from external and internal constraints which is a constraint for the government in the preservation of Bilih fish populations in the use of Centrum, Putas/poison, and nets and mesh that the net eyes are too tightly in Lake Singkarak. Third, the efforts undertaken by the local government in stopping the constraints that occur: 1) DKP that conducts coaching to the fishermen community in providing training, awareness, counseling, and socialization of the preservation of the population of Bilih fish in Lake Singkarak; 2) The Government has the purpose of providing the assistance of an environmentally friendly arrest tool to the fishermen who operate the fishing equipment in the lake Salingka; 3) Conduct raids to the fishermen communities that operate the use of Centrum, Putas/poison, the vacuum and nets that the net eye is too tightly in Lake Singkarak; 4) The plan to propose the government budget to the preservation of Bilih fish in Lake Singkarak has not been running in accordance with the role of the Government on the construction and supervision of this still many fishermen people who use the Centrum, Putas/poison, the vacuum and nets that the net is too tightly in Lake Singkarak.
\end{abstract}

Keywords : Roles, Constraints, Efforts of Local Governance

Corresponding author. Email.intanelmayu08@gmail.com, syamsirsaili@yahoo.com

How to cite this article. Putri, I. Elmayu \& Syamsir. (2020). Implementasi Peran Pemerintahan Daerah dalam Pelestarian Populasi Ikan Bilih di Danau Singkarak Berdasarkan Peraturan Gubernur Nomor 81 Tahun 2017. Jurnal Mahasiwa Ilmu Administrasi Publik (JMIAP) Jurusan Ilmu Administrasi Negara Fakultas Ilmu Sosial Universitas Negeri Padang, Volume 2 (2), Hal. 128-137.

http://jmiap.ppj.unp.ac.id

ISSN : 2684-818X (Online), ISSN : 2338-7378 (Print)

Copyright $(2020$. Published by Pusat Kajian-Pemberdayaan dan Pelayanan Masyarakat (PK-P2M) FIS UNP Padang 


\section{PENDAHULUAN}

Provinsi Sumatra Barat merupakan salah satu pulau yang mempunyai keindahan alam dan danaunya. Sumatera Barat mempunyai lima danau yang dapat mendukung potensi perikanan di perairan umum. Kelima danau tersebut adalah Danau Maninjau, Danau Diateh dan Dibawah, Talang dan Singkarak. Dari danau diatas tersebut terdapat danau yang terluas yaitu Danau Singkarak. Danau Singkarak merupakan danau yang terletak di Kabupaten Tanah Datar dan Kabupaten Solok dengan luas permukaan $11.200 \mathrm{Ha}$ (Syandri, 2008).

Danau Singkarak merupakan danau terluas di Sumatera Barat yang memiliki populasi perairan yang khas. Populasi merupakan sekelompok individu dengan karakteristik serupa atau satu spesies dan yang hidup di tempat yang sama serta memiliki kemampuan untuk memproduksi sesuai dengan spesiesnya sendiri. Populasi adalah sekumpulan manusia, hewan dan tumbuh-tumbuhan serta benda-benda yang memiliki karakteristik tertentu dan populasi ini menjadi tempat untuk mengeneralisasikan karakteristik tersebut dalam menyimpulkan hasil penelitian yang dilakukan (Mulyatiningsih, 2011:19).

Sebagian besar masyarakat nelayan yang berada disekitar Danau Singkarak, menjadikan perikanan sebagai mata pencarian mereka untuk meningkatkan pertumbuhan ekonomi dan sumber penghasilan masyarakat serta sebagai asset bangsa yang sangat penting. Salah satu cara yang dilakukan untuk meningkatkan pendapatan nelayan yaitu dengan meningkatkan produksi hasil tangkapan. Dengan meningkatnya produksi hasil tangkapan, nelayan harus mengusahakan unit penangkapan yang produktif dan tinggi dalam jumlah serta tinggi dalam nilai hasil tangkapannya. Salah satu unit penangkapan ikan tersebut harus bersifat ekonomis, efisien dan menggunakan teknologi yang sesuai dengan kondisi mereka dan tidak merusak kelestarian ikan dan sumberdaya perikanan.
Masyarakat nelayan mempunyai tujuan sebagai kelompok yang secara langsung memanfaatkan sumber daya perikanan melalui kegiatan tangkap dan budidaya yang tidak terlepas dari masalah kemiskinan. Masyarakat nelayan merupakan bagian dari kelompok masyarakat yang tinggal di daerah pesisir. Pada umumnya mereka adalah kelompok masyarakat tertinggal yang berada pada level paling bawah, baik tertinggal secara ekonomi, sosial, maupun budaya. Karena penghasilan mereka masih tergantung pada kondisi alam, maka sulit bagi mereka untuk merubah kehidupannya menjadi lebih baik. Sebagai nelayan tradisional tidak hanya berhadapan dengan masalah pendapatan dan tekanan musim yang panjang, melainkan mereka juga mengalami masalah dalam pengelolaan keuangan dan pemasaran hasil produksinya. Sehingga hasil produksi disekitar Danau Singkarak tersebut bermata pencarian menangkap ikan.

Danau Singkarak memiliki beraneka ragam jenis ikan, salah satunya adalah ikan Bilih yang merupakan ikan endemik dari Danau Singkarak (Syandri, 2008). Ikan Bilih (Mystacoleuseus padangensis) merupakan komoditas perikanan yang memiliki nilai ekonomi yang tinggi dengan harga yang relatif mahal dan wilayah pemasaran yang luas. Ikan Bilih ini adalah salah satu potensi lokal yang dimiliki oleh daerah Sumatera Barat yang hidup di sekitar Danau Singkarak. Ikan dengan nama latin Mystacoleuseus padangensis memiliki ukuran sedikit lebih besar dari ikan teri, yang berbentuk lonjong dan pipih dengan panjang 6-12 cm.

Secara ekonomi ikan Bilih memberikan dampak yang positif dikarenakan merupakan sumber pendapatan masyarakat nelayan sekitar Danau Singkarak dan memiliki dampak yang negatif dari dorongan ekonomi, sehingga menyebabkan terjadinya eksploitasi berlebihan dan masyarakat nelayan seringkali melakukan peristiwa-peristiwa yang sedang terjadi atau yang telah terjadi (tindakan deskritif) yang 
mengancam keberadaan ikan dengan melakukan penangkapan mengunakan alat tangkap ikan yang tidak ramah lingkungan.

Penggunaan penangkapan yang tidak ramah lingkungan tersebut mengakibatkan kondisi populasi ikan di Danau Singkarak semakin rusak. Menurut Syandri (2008), menyatakan penyebab terancam punahnya ikan Bilih di picu oleh cara tangkap dan alat yang digunakan masyarakat nelayan yang tidak ramah lingkungan. Jenis alat tangkap ikan yang digunakan nelayan sekitar danau singkarak yaitu jaring panjang, jaring lingkar, sistem alahan, jala, sentrum, putas atau racun, bagan yang menggunakan arus listrik bahkan ada juga yang menggunakan alat peledak bom. Alat tangkap ikan yang digunakan nelayan sekitar danau singkarak memiliki ukuran yang sangat rapat sekitar 1-1,5 cm, sehingga mengakibatkan banyaknya anak ikan yang tertangkap oleh jaring maupun jala yang di gunakan masyarakat nelayan tersebut.

Namun penggunaan tangkap ikan yang mengandung zat-zat kimia, bahan biologis (racun atau putas), jaring, pengebonan dan sentrum ini mengakibatkan terancamnya populasi ikan, sehingga merusak kelestarian lingkungan dan sumberdaya ikan lainnya. Karena penangkapan tersebut mengakibatkan kepunahan ikan Bilih secara terus-menerus atau setiap tahunnya. Dalam menangkap ikan secara terus-menerus tersebut mengalami kepunahan atau mengancam populasi dan ikan Bilih sulit melakukan regenerasi dan reproduksi di Danau Singkarak.

Pemerintah Daerah yang bertugas sebagai menjaga dan melestarikan kelestarian ikan agar tidak mengalami kepunahan setiap tahunnya, maka pemerintah melakukan perannya dalam memberikan pembinaan dan pengawasan kepada masyarakat nelayan terhadap pelestarian populasi ikan Bilih di Danu Singkarak yang menggunakan alat tangkap sentrum, putas/racun, bahan peledak dan jala yang mata jaring terlalu rapat tersebut. Sehingga peran pemerintah tersebut belum optimal dalam menjalankan pembinaan dalam bentuk sosialisasi, pelatihan, bimbingan dan penyuluhan serta dalam menjalankan pelaksanaannya dalam bentuk pengawasan kepada masyarakat nelayan yang mata pencahariannya sebagai menangkap ikan dan masih mengoperasikan alat tangkap tersebut di Danau Singkarak.

Untuk menjaga dan meningkatkan populasi Sumber Daya ikan khususnya ikan Bilih dari ancaman kepunahan, perlu diatur penggunaan alat dan bahan penangkapan ikan di Danau Singkarak. Hal ini sesuai dengan Peraturan Gubenur Sumatera Barat Nomor 81 Tahun 2017 tentang penggunaan alat dan bahan penangkapan ikan yang dapat merusak kelestarian Sumber Daya ikan di Perairan Danau Singkarak. Dalam Peraturan Gubenur No. 81 Tahun 2017 yang mempunyai substasi dalam menjalankan perannya yaitu dalam memberikan pembinaan dan pengawasan kepada masyarakat. Pembinaan terhadap masyarakat nelayan di Perairan Danau Singkarak dilakukan oleh Gubernur dan pelaksanaan pembinaan tersebut dilakukan oleh Kepala Dinas serta peran dari pembinaan tersebut dilakukan melalui sosialiasi, pelatihan, bimbingan, dan penyuluhan. Sedangkan peran dalam pengawasan yang terdapat dalam Peraturan Gubenur di atas terdiri dari pengawasan terhadap penggunaan alat dan bahan penangkapan ikan di Perairan Danau Singkarak dilakukan oleh pengawas perikanan, pengawas perikanan yang terdiri dari PPNS Perikanan, Pengawas Perikanan yang diangkat oleh Menteri dan aparat Kepolisian Republik Indonesia dan pengawasan penggunaan alat dan bahan penangkapan ikan di Perairan Danau Singkarak oleh pengawas perikanan yang dilakukan sesuai dengan ketentuan peraturan perundangan-undangan.

Dengan adanya peraturan tersebut maka upaya pemerintahan daerah dalam melestarikan populasi ikan Bilih yaitu dengan menjaga kelestarian ikan Bilih tersebut agar tidak mengalami kepunahan. Salah satu upaya pelaksanaan penerapan 
yang dilakukan pemerintah adalah melakukan pengawasan populasi ikan Bilih. Berdasarkan pengertiannya sendiri penerapan/implementasi merupakan penerapan dalam pelaksanaan suatu pekerjaan, kepemimpinan, dan cara bertindak tentang pemerintahan dan organisasi untuk manajemen dalam usaha mencapai sasaran dan mencapai tujuan. Menurut Mulyadi (2015:12) Implementasi merupakan suatu rangkaian aktivitas dalam rangka menghantarkan kebijakan kepada masyarakat sehingga kebijakan tersebut dapat membawa hasil sebagaimana yang diharapkan. Pada dasarnya implementasi suatu program telah ditetapkan oleh pemerintah harus sejalan dengan kondisi yang ada, baik itu dilapangan maupun diluar lapangan, yang mana dalam kegiatannya melibatkan beberapa unsur disertai dengan usaha-usaha dan dukungan oleh alat-alat penunjang. Kebijakan yang diimplementasikan oleh pemerintah biasanya berbentuk sebuah program yang kemudian program tersebut dapat dirasakan dan bermanfaat bagi masyarakat. Salah satu bentuk program/Dinas yang diterapkan oleh pemerintah dalam pelestarian populasi ikan Bilih adalah Dinas Kelautan dan Perikanan (DKP) Provinsi Sumatera Barat.

Dinas Kelautan dan Perikanan (DKP) Provinsi Sumatera Barat berupaya menjaga populasi perikanan di Danau Singkarak dengan melakukan pelarangan pemakaian alat penangkapan ikan yang merusak populasi ikan Bilih namun upaya ini tidak diindahkan atau diabaikan oleh oknumoknum masyarakat nelayan. Masyarakat nelayan merupakan sekelompok orang yang mengantungkan hidupnya pada hasil tangkapan ikan yang ada di wilayah pesisir, namun teknologi yang digunakan untuk tangkapan ikan adalah Masyarakat nelayan banyak mengunakan penangkapan ikan dengan bahan tangkapan yang mengancam populasi ikan sehingga ikan mengalami kepunahan setiap tahunnya.

Dinas Kelautan dan Perikanan (DKP) Provinsi Sumatera Barat yang mempunyai tujuan sebagai upaya menjaga kelestarian ikan Bilih yang mulai punah karena mengunakan sistem penangkapan dengan menggunakan sentrum listrik, dan dengan penangkapan menggunakan racun/putas serta penangkapan dengan menggunakan pukat harimau, sehingga DKP melakukan penertiban yang dilaksanakan di Danau Singkarak agar langkah tersebut dapat meningkatkan populasi ikan asli Danau Singkarak yang kini mulai berkurang dan tindakan yang dilakukan DKP tersebut sebagai upaya menyelamatkan populasi ikan Bilih yang ada di danau singkarak. Karena penangkapan ikan tersebut menyebabkan kepunahan ikan Bilih dalam skala yang cukup besar, sehingga penangkapan ikan yang dilakukan secara terus-menerus tersebut mengalami kepunahan atau mengancam populasi ikan Bilih di Danau Singkarak.

Berdasarkan latar belakang masalah di atas, maka peneliti tertarik untuk melakukan penelitian dengan judul "Implementasi Peran Pemerintahan Daerah dalam Pelestarian Populasi Ikan Bilih Di Danau Singkarak Berdasarkan Peraturan Gubenur Sumatera Barat No. 81 Tahun 2017".

\section{TINJAUAN PUSTAKA \\ Kebijakan Publik dan Implementasi Kebijakan}

Kebijakan publik merupakan suatu proses dalam mengatur, mengelola dam menyelesaikan berbagai urusan, masalah publik dan sumber daya agar mencapai tujuan yang telah disepakati bersama (Mulyadi, 2015).

Sedangkan implementasi kebijakan adalah suatu cara agar mancapai tujuan dalam sebuah kebijakan ( Nugroho, 2014:4)

\section{Peran Pemerintah}

Peran pemerintah merupakan suatu peran pemerintah dalam membangun masyarakat dalam membangun kemampuan seseorang dan menjalankan tugas serta fungsinya dalam menyelesaikan persoalan yang berada dilingkungan masyarakat ataupun pemerintah ( Ndraha, 1987:110). 
Peran pemerintah sangat penting dan strategis dalam penyelenggaraan kehidupan bernegara. Penyelenggaraan kehidupan bernegara bertujuan untuk mencapai tujuan negara, yakni untuk melindungi dan meningkatkan kualitas kehidupan semua warganya. Keberhasilan suatu rezim pemerintahan sebagai penyelenggaraan negara sangat ditentukan oleh perannya untuk mensejahterakan masyarakat. Oleh karena itu, setiap pemerintahan seyogyanya perlu memikirkan kesejahteraan rakyat secara keseluruhan. Pemerintahan tidak boleh hanya terpaku memikirkan bagaimana meningkatkan pendapat negara atau daerah, semisal pajak dan destribusi lainnya tetapi justru yang lebih penting dan utama adalah bagaimana meningkatkan pendapatan dan kesejahteraan masyarakat.

\section{Lingkungan Hidup dan Upaya Pelestariannya}

Menurut Soemarwoto (2005) lingkungan merupakan suatu hal yang tidak dapat dipisahkan dari kehidupan makhuk hidup dan lingkungannya.

Sedangkan pelestarian lingkungan hidup merupakan tanggung jawab bersama pemerintah dan masyarakat yang mempunyai kewajiban melestariakn lingkungan hidip agar terjaga kelestariannya ( UU No. 32 Tahun 2004).

\section{Kendala-kendala dalam Pelestarian Lingkungan}

Kendala dalam KBBI (Poerwadarminta, 2008:75) merupakan suatu rintangan dan hambatan yang dihadapi seseorang sebagai suatu masalah yang dapat mengahambat tujuannya dalam mencapai tujuan.

\section{METODE PENELITIAN}

Penelitian ini menggunakan penelitian Penelitian kualitatif, penelitian dilaksanakan oleh Pemerintah Daerah, Walinagari dan pemuka masyarakat serta masayarakat nelayan. Dalam menentukan informan penelitian pemerintah memberikan pertimbangan berdasarkan informasi dengan semaksimal mungkin kepada kelompok masyarakat nelayan dan kepada pihak yang terlibat dalam memberikan informasi yang peneliti butuhkan. Jenis pengambilan data dalam penelitian ini didapatkan melalui data primer yaitu observasi dan wawancara langsung kepada masyarakat yang berkaitan tentang Implementasi Peran Pemerintahan Daerah dalam Pelestarian Populasi ikan Bilih di Danau Singkarak Berdasarkan Peraturan Gubenur Sumatera Barat No. 81 Tahun 2017. Selain data primer penelitian ini juga bersumber dari data sekunder yang didapatkan melalui studi dokumentasi di lapangan. Uji keabsahan menggunakan sumber check dan triangulasi teknik dengan membandingkan dan mengecek darimana sumber atau informasi yang peneliti dapatkan dari wawancara langsung dengan masyarakat, observasi dan studi dokumentasi.

\section{HASIL DAN PEMBAHASAN \\ Peran Pemerintahan Daerah dalam Pelestarian Populasi Ikan Bilih di Danau Singkarak}

Pemerintah Daerah yang mempunyai peran yang sangat penting dalam pelestarian populasi ikan Bilih dalam melakukan pembinaan dan pengawasan kepada nelayan yang mata pencahariannya sebagai menangkap ikan antara lain:

a) Pemerintah memberikan pembinaan berupa sosialisasai, bimbingan dan pelatihan serta penyuluhan yang dilaksanakan oleh Dinas Kelautan dan Perikanan dan pelaksanaannya dilakukan oleh Kepala Dinas Perikanan Tangkap Provinsi Sumatera Barat. Dalam hal ini Pemerintah Daerah bertujuan dalam melestariakan populasi ikan Bilih di Danau Singkarak yang dilakukan oleh DKP dalam memberikan pembinaan berupa sosialisasi, pelatihan, bimbingan dan penyuluhan terhadap penggunaan alat tangkap yang berupa sentrum, putas/racun, bahan peledak serta jaring kepada masyarakat nelayan. 
b) Pengawasan. Pengawasan terhadap pelestarian populasi ikan Bilih yang mengunakan penangkapan ikan yang tidak ramah lingkungn di salingka Danau yang dilaksanakan oleh kelompok masyarakat pengawas dan pihak-pihak yang terlibat dalam pengawasan terdiri dari pengawasan yang dilakukan oleh Aparat Kepolisian dan PPNS. Dalam melaksanakan pengawasan dalam pelestarian populasi ikan, pengawasan tersebut memiliki kewenangan untuk membawa, memotret, menangkap, memeriksa dan menghentikan pelaku dalam tindak pidana serta penggunaan sentrum, putas/racun dan pengebonan serta jala tersebut melakukan pelanggaran dan tindak pidana kepada masyarakat nelayan yang mengoperasikan alat tangkap tersebut di salingka danau (Peraturan Gubenur Sumatera Barat No. 81 Tahun 2017).

Berdasarkan wawancara peneliti dengan Pemerintahan Daerah yang mengatakan bahwa Pemerintah Daerah sudah melakukan pembinaan sesuai dengan Pergub Sumbar No. 81 tahun 2017 yang berbunyi bahwa bahan dan alat tangkap yang dilarang dioperasikan di salingka danau tidak diperbolehkan menggunakan alat tangkap berupa sentrum, putas/racun dan pengebonan serta jala tersebut di salingka danau. Dalam memberikan sosialisasi Pemerintah Daerah sudah memberikan sosialisasi di Kabupaten Solok pada tanggal 30 April 2019 dan melaksanakan pengawasan dalam bentuk razia gabungan di Danau Singkarak.

\section{Kendala yang ditemukan Pemerintah Daerah dalam Pelestarian Populasi Ikan Bilih di Danau Singkarak}

Dalam menjalankan perannya Pemerintah Daerah terhadap pelestarian populasi ikan yang menggunakan sentrum, putas/racun dan pengebonan serta yang menggunakan jala dengan mata jaring terlalu rapat yang dilarang sudah melakukan penyuluhan, pelatihan, bimbingan dan sosilisasi serta pengawasan kepada kelompok nelayan. Peran Dinas Kelautan dan Perikanan Provinsi Sumatera Barat sering dihadapi dengan kendala eksternal dan internal yang ditemui dalam wawancara dengan informan antara lain:

\section{Faktor Eksternal}

Ada beberapa faktor eksternal yang ditemui Pemerintah dalam upaya pelestarian populasi ikan Bilih di Danau Singkarak yaitu: Pertama, Ketergantungan Masyarakat Nelayan terhadap pelestarian Populasi ikan Bilih di Danau Singkarak dimana masyarakat yang mengantungkan hidup dari menangkap ikan menggunakan sentrum, putas/racun dan pengebonan serta jala yang mata jaring terlalu rapat yang dilarang di danau tersebut. Hal ini dapat mempengaruhi upaya Dinas Kelautan dan Perikanan Provinsi Sumatera Barat dalam pelestarian populasi ikan Bilih di Danau Singkarak. Ketergantungan masyarakat tersebut dikarenakan faktor lingkungan. Menurut Soemarwoto (dalam Ahmad 2014) Lingkungan merupakan suatu hal yang tidak dapat dipisahkan dalam kehidupan makhluk hidup yang sangat bergantung dari mereka sendiri baik dari manusia itu sendiri maupun tumbuh-tumbuhan yang sangat bergantung pada lingkungan tempat mereka hidup. Kedua, masyarakat nelayan yang tinggal di tepian sunggai dan dikelilingi oleh bukit dan danau yang sangat mempunyai pekerjaan menangkap ikan dan dengan keterbatasan lahan tersebut maka ini menjadi kendala dari Pemerintah dalam pelestarian populasi ikan Bilih di Danau Singkarak. Dengan adanya keterbatasan suatu lahan tersebut membuat nelayan salingka danau hanya dapat bekerja sebagai menangkap ikan, karena kelompok nelayan memanfaatkan perairan danau untuk meningkatkan taraf hidupnya sebagai menangkap ikan. Ketiga, Sikap Prilaku Masyarakat Nelayan terhadap pelestarian populasi ikan dimana mereka tidak mau adanya dampak yang akan terjadi akibat 
ulah mereka sendiri agar mereka meraih keuntungan yang besar, tetapi masyarakat nelayan tidak menyadari dengan dampak tersebut mengancam pelestarian populasi ikan dan sumber daya lainnya.

Berdasarkan wawancara peneliti dengan Pemerintah Daerah, Dinas Kelautan dan Perikanan Provinsi Sumatera Barat terdapat beberapa kendala yang dihadapi dalam melakukan perannya antara lain: ketergantungan masyarakat nelayan dalam pelestarian Populasi ikan yang menangkap ikan dengan sentrum, putas/racun, pengebonan serta jala yang mata jaring terlalu rapat; masyarakat nelayan di tepi sunggai dan danau yang dikelilingi perbukitan sangat terbatas dengan lahan yang mereka miliki sehingga mereka tidak mempunyai lahan untuk diolah; masyarakat yang tidak peduli dengan keselamatan lingkungan dan sikap prilakunya yang tidak sadar dengan dampak yang akan timbul akibat mereka masih mengoperasikan alat tangkap berupa sentrum, putas/racun, pengebonan serta jala yang mata jaring terlalu rapat tersebut akan merusak kelestarian lingkungan.

\section{Kendala Internal}

Disamping kendala eksternal, terdapat pula kendala internal yang ditemui oleh Dinas Kelautan dan Perikanan Provinsi Sumatera Barat dalam pelestarian Populasi ikan Bilih di Danau Singkarak antara lain :

1) Pemerintah Daerah sudah memberikan anggaran kepada masyarakat nelayan tetapi hanya bagi masyarakat yang taat sama aturan. Masyarakat nelayan tidak mau menghentikan alat tangkap mereka dikarenakan mereka sangat tergantung pada penangkapan ikan dan ini merupakan kendala yang sulit dicarikan solusinya oleh pemerintah dan pemerintah tidak mempunyai anggaran untuk mengantikan larangan menangkap ikan tersebut untuk semua masyarakat yang berada di salingka Danau Singkarak.
2) Pemerintah Daerah dalam melakukan sistem struktur birokrasi yang terhambat tersebut merupakan kendala yang dihadapi pemerintah dalam melestarikan populasi ikan di salingka danau. Standar Operasional Prosedur tidak dapat melakukan kegiatan secara langsung memberikan sosialisasi dalam SOP tersebut dikarenakan ini merupakan wewenang dari Pemerintah Daerah (UU No. 23 Tahun 2014).

Berdasarkan wawancara diatas dengan Dinas Kelautan dan Perikanan Provinsi Sumatera Barat bahwa anggaran untuk sosialisasi alat tangkap yang berupa sentrum, putas/racun, bahan peledak serta jala yang mata jaringnya terlalu rapat tersebut belum mencukupi untuk masyarakat nelayan yang ada di Danau Singkarak. Dan sistem struktur birokrasi yang terhambat menjadi kandala bagi Pemerintah Daerah.

Dalam Pelestarian Populasi Ikan Bilih Pemerintah Daerah berupaya mengatasi kendala yang terjadi di salingka Danau Singkarak. Dengan peneliti wawancara langsung oleh Dinas Kelautan dan Perikanan Tangkap dan Pengelolaan Ruang Laut dan Pengawasan SDKP Dinas Kelautan dan Perikanan Provinsi Sumatera Barat berupaya:

a) Memberikan sosialisasi, penyadaran dan penyuluhan langsung kepada nelayan yang dilakukan oleh Pemerintah Daerah dalam kendala yang timbul dan cara mengatasinya dengan melakukan sosialisasi, penyadaran dan penyuluhan kepada nelayan yang menggunakan alat tangkap sentrum, putas/racun, bahan peledak serta yang menggunakan jala yangmata jaring terlalu rapat tersebut dan mereka yang bekerjasama dengan tokoh masyarakat atau kelompokkelompok masyarakat pengawas serta pihak-pihak yang terlibat dalam memberikan sosilisasi, masyarakat nelayan yang belum sadar dengan 
bencana yang akan timbul jika mereka tetap mengoperasikan alat yang dilarang tersebut salingka Danau Singkarak.

b) Pemerintah Daerah yang berupaya dalam memberikan bantuan berupa alat tangkap yang ramah dengan lingkungan kepada kelompok nelayan supaya tidak menggunakan alat tangkap berupa sentrum, putas/racun, pengeboman dan jala yang mata jaring terlalu rapat tersebut sehingga kelestarian populasi ikan Bilih di salingka danau tidak terancam kepunahan.

c) Pemerintah Daerah berupaya melaksanakan razia gabungan di salingka danau kepada nelayan yang bertahan dengan alat tangkapnya berupa sentrum, putas/racun dan pengebonan serta jala yang mata jaringnya terlalu rapat ini di salingka danau.

Berdasarkan peneliti wawancara langsung dengan Kepala Perikanan Tangkap dan Pengelolaan serta Pengawasan SDKP, beliau mengatakan upaya yang dilakukan Pemerintah Daerah dalam pelestarian Populasi ikan Bilih di Danau Singkarak adalah memberikan sosialisasi, kesadaran dan penyuluhan kepada masayarakat yang masih mengoperasikan alat tangkap seperti sentrum, putas/racun, pengebonan serta jala yang mata jaring terlalu rapat agar memberikan bantuan alat tangkap yang tidak merusak dan melaksanakan razia di salingka danau tdan masyarakat tidak taat dengan aturan akan diberikan bantuan oleh pemerintah.

\section{PENUTUP}

Dalam hasil temuan yang peneliti dapatkan di Dinas Kelautan dan Perikanan Provinsi Sumatera Barat dapat ditarik kesimpulannya yaitu :

1) Peran Dinas Kelautan dan Perikanan Provinsi Sumatera Barat Dinas Kelautan dan Perikanan Provinsi Sumatera Barat mempunyai peran yang sangat penting terhadap pelestarian
Populasi ikan Bilih di Danau Singkarak Peraturan Gubenur Sumatera Barat Nomor 81 Tahun 2017 tentang penggunaan alat dan bahan penangkapan ikan yang dapat merusak kelestarian Sumber Daya ikan di Perairan Danau Singkarak. Dalam Peraturan Gubenur No. 81 Tahun 2017 yang mempunyai substasi dalam menjalankan perannya yaitu dalam memberikan pembinaan dan pengawasan kepada masyarakat. Pembinaan terhadap masyarakat nelayan di Perairan Danau Singkarak dilakukan oleh Gubernur dan pelaksanaan pembinaan tersebut dilakukan oleh Kepala Dinas serta peran dari pembinaan tersebut dilakukan melalui sosialiasi, pelatihan, bimbingan, dan penyuluhan. Sedangkan peran dalam pengawasan yang terdapat dalam Peraturan Gubenur di atas terdiri dari pengawasan terhadap penggunaan alat dan bahan penangkapan ikan di Perairan Danau Singkarak dilakukan oleh pengawas perikanan, pengawas perikanan yang terdiri dari PPNS Perikanan, Pengawas Perikanan yang diangkat oleh Menteri dan aparat Kepolisian Republik Indonesia dan pengawasan penggunaan alat dan bahan penangkapan ikan berupa sentrum, putas/racun dan pengebonan serta yang mengunakan jala dengan mata jaring yang terlalu rapat tersebut di Perairan Danau Singkarak oleh pengawas perikanan yang dilakukan sesuai dengan ketentuan peraturan perundanganundangan.

2) Kendala yang dihadapi Dinas Kelautan dan Perikanan Provinsi Sumatera dalam Pelestarian Populasi Barat ikan Bilih di Danau Singkarak berdasarkan Peraturan Gubenur No. 81 Tahun 2017 terdapat kendala internal dan kendala eksternal yang dihadapi oleh Dinas Kelautan dan Perikanan Provinsi Sumatera Barat adalah : 1) ketergantungan masyarakat nelayan terhadap pelestarian populasi ikan yang menggunakan penangkapan 
yang berupa sentrum, putas/racun, pengeboman dan jala yang mata jaring terlalu rapat di salingka Danau Singkarak; 2) Keterbatasan lahan bagi masyarakat nelayan yang bertempat tinggal di muara sungai dan dikelilingi oleh bukit serta yang berada ditepian Danau Singkarak; 3) Faktor sikap prilaku masyarakat nelayan Danau Singkarak yang tidak peduli dengan keselamatan lingkungan. Adapun dari DKP Provinsi Sumatera Barat terdapat beberapa faktor internal dari Pemerintah Daerah sudah memberikan anggaran kepada masyarakat nelayan tetapi hanya bagi masyarakat yang taat sama aturan dan Pemerintahan Daerah dalam melakukan sistem struktur birokrasi yang terhambat tersebut merupakan kendala yang dihadapi pemerintah dalam melestarikan populasi ikan Bilih di salingka Danau Singkarak.

3) Upaya yang dilakukan Pemerintah Daerah yaitu emberikan sosialisasi, penyadaran dan penyuluhan langsung kepada nelayan yang dilakukan oleh Pemerintah Daerah dalam kendala yang timbul dan cara mengatasinya yakni; 1) melakukan sosialisasi, penyadaran dan penyuluhan kepada nelayan yang masih mengoperasikan alat tangkap berupa sentrum, putas/racun, bahan peledak serta yang menggunakan jala yang mata jaring terlalu rapat. 2) Pemerintah Daerah yang berupaya memberikan bantuan alat tangkap ramah dengan lingkungan kepada kelompok nelayan supaya tidak menggunakan alat tangkap tersebut sehingga kelestarian populasi ikan Bilih di salingka danau tidak terancam kepunahan 3) Pemerintah Daerah berupaya melaksanakan razia gabungan di salingka danau kepada nelayan yang bertahan dengan alat tangkapnya berupa sentrum, putas/racun dan pengebonan serta jala yang mata jaringnya terlalu rapat ini di salingka danau. 4) Pihak DKP mengusulkan anggaran terhadap pelestarian populasi kepada pemerintah.
Menurut Mardiasmo (dalam Irfan Fatoni, 2013) mengatakan bahwa anggaran sektor publik ini merupakan salah satu alat dari pemerintah dalam mengarahkan pembangunan yang menjamin kesinambungan agar pembangunan tersebut dapat meningkatkan kualitas hidup masyarakat. Anggaran tersebut diberikan karena ini merupakan kebutuhan dan keinginan dari masyarakat yang berkembang, sumberdaya ini terbatas dan anggaran tersebut merupakan instrumen dari pelaksanaan yang dilaksanakan dalam akuntabilitas publik oleh lembaga pemerintahan dan instansi.

Dengan hasil penelitian "Implementasi Peran Pemerintahan Daerah dalam Pelestarian Populasi Ikan Bilih di Danau Singkarak berdasarkan Peraturan Gubenur Sumatera Barat No. 81 Tahun 2017, peneliti memberikan saran yaitu: agar Pemerintah Daerah meningkatkan lagi perannya dalam memberikan sosialisasi dan penyuluhan serta dalam pelaksanaan pengawasannya ditingkatkan lagi agar tidak mengoperasikan alat tangkap seperti sentrum, putas/racun, pengebonan serta jala yang mata jaring terlalu rapat di salingka danau; agar Pemerintah Daerah memberikan solusi agar kendala eksternal dan internal yang berasal dari masyarakat sendiri agar tidak mengoperasikan alat tangkap seperti sentrum, putas/racun, pengebonan serta jala yang mata jaring terlalu rapat di salingka Danau Singkarak.

\section{DAFTAR KEPUSTAKAAN}

Ahmad Taufiq. 2014. Upaya Pemeliharaan Lingkungan oleh Masyarakat di Kampung Sukadaya Kabupaten Sabang. Universitas Pendidika. Jurnal Gea. Vol. 14 No. 2.

Angraini, Lia dan Syamsir. 2019. Peran Dinas Kelautan Dan Perikanan Provinsi Sumatera Barat Dalam Mengatasi Bagan Tangkap Ikan Di Perairan Danau Singkarak. Journal of Education on Social Science. Vol. 3 Nomber 1 Hal. 24-33. 
Fantoni, Irfan. 2013. Pengaruh Anggaran dan Pengendalian Terhadap Efektivitas Kinerja Satuan Kerja Perangkat Daerah di Kabupaten Malang, Malang. Jurnal Manajemen dan Akuntasi. Vol 2 No 3.

Muchlisin, Z. A., Siti Azizah M.N, Edi Rudi dan Nur Fadli. 2009. Danau Laut Tawar dan permasalahannya. http://winbathin.blogspot.com/2009.

Mulyatiningsih, Endang. 2011. Metode Penelitian Terapan Bidang Pendidikan. Bandung: Alfabeta.

Peraturan Gubenur Sumatera Barat Nomor 81 Tahun 2017 Tentang larangan mengunakan alat dan bahan penangkapan ikan yang dapat merusak kelestarian Sumber Daya ikan di Perairan Danau Singkarak.

Rahmadi, Takdir. 2012. Hukum Lingkungan di Indonesia. Jakarta: PT Rajagrafindo Persada.

Susi, Hendriani. 2008. Pengaruh Pelatihan dan Pembinaan. Kependududkan UNPAD. Vol. 10 No. 2 Hal: 152-168.

Syandri H. 2008. Aspek Reproduksi Ikan Bilih, Mystacoleuseus Pandangensis Bleeker dan Kemungkinan Pembenihan di Danau Singkarak. Tesis Pascasarjana Biologi, Institut Pertanian Bogor. Bogor.

Undang-Undang Nomor 23 Tahun 2014 Tentang Pemerintahan Daerah. 